\title{
Dysfunctional Consumer Behavior: Proposition of a Measurement Scale
}

\author{
Marília Lara Marcondes Machado de Oliveira ${ }^{\dagger}$ \\ Strong Higher Education Center \\ Andres Rodriguez Veloso ${ }^{\Omega}$ \\ University of São Paulo
}

\begin{abstract}
This study focuses on the development of a scale that can identify customers that are more prone to behave in a dysfunctional manner. Dysfunctional Consumer Behavior can negatively influence the organization profits, since this kind of consumer can generate monetary losses, such as fixing damaged property. Several hypotheses are proposed based on consumer characteristics that could foster dysfunctional behavior. For this, we used an hybrid methodology, combining Churchill's (1979) with C-OAR-SE (2002). In order to develop the scale, scenarios with dysfunctional behaviors where constructed. Respondents were asked to rate the appropriateness of each behavior and answers a group of questions based on the hypothesis developed. The data was collected over the Internet (Amazon Turk) and the statistical methods used for the scale development were cluster and discriminant analysis. The results showed evidence that it is possible to distinguish consumers through a discriminant function using interpersonal influence, such as aggressiveness, self-exposure, moral flexibility and machiavellianism; and personality aspects, such as dissatisfaction and acceptance.
\end{abstract}

Keywords: Consumer behavior. Consumer satisfaction. Marketing.

*Author for correspondence:

${ }^{\dagger}$ Professor

Institutionon: Strong Higher Education Centre

Address: Av Industrial, 1455, Bairro Jardim

09080-510, Sando André - SP - Brazil

E-mail: marilia.lara.mm@gmail.com

Telephone: +55 $114433-6161$

\footnotetext{
$\Omega$ Associated Professor

Institution: University of São Paulo

Address: Av. Prof. Luciano Gualberto 908, FEA1, Sala E204. 1, Cidade

Universitária, 05508-010, São Paulo - SP - Brazil

E-mail: veloso@usp.br

Telephone: $+55113091-5879$
}

Note from the Editor: The article was accepted by Emerson Mainardes. 


\section{INTRODUCTION}

he belief that the customer is always right is so powerful that it ended up gaining a status of common sense (HARRIS; REYNOLDS, 2003). However, this is not always true, and ends up being used to rationalize the dysfunctional consumer behavior (FULLERTON; PUNJ, 2004; NEALE; FULLERTON, 2010), which can be understood as behavior adopted by certain consumers that is against the rules and regulations established by the society in which they are inserted, during the consumption of a product and/or service (FISK et al., 2010).

Some examples of such behaviors are the consumers that argue violently with attendants because they doesn't agree with something that happened, or consumers that take advantage of return policies looking to take some advantage - keeping the label in a dress to return it to the store after a huge party. Another typical case of dysfunctional behavior are the situations when consumers fight with each other, or consumes some food at the supermarket without paying for it at the check-out. Such behaviors, as can be seen, end up bringing not only financial losses, but can implicate in image impact too.

Studies in the field of Consumer Behavior have discussed the issue of such behavior and provide evidence that it has been occurring quite often, and that companies end up being afraid with regard to the way they should deal with this customers (WIRTZ; KUM, 2004; REYNOLDS; HARRIS, 2005). As a result, companies often create rigid customer service policies, looking to avoid this kind of behavior (WIRTZ; KUM, 2004).

Considering the losses and problems that customers that behave this way can cause, we believe that it is important to have a method to identify them. Thus, companies can monitor the behavior of these consumers, avoiding the problems that they can generate undermining the provision of services, both for themselves and for other consumers.

The scale developed in this article is constructed using indirect variables that can highlight consumers that are more likely to act in a dysfunctional way. Thereby, companies can use this scale as a questionnaire applied in to consumers that interact whit them. If the company figures out that the consumer tend to have a dysfunctional behavior, it can use a different consumer policy - that can inhibit this behavior.

For example, if some dysfunctional consumer calls to the company complaining about some product that he bought, the company can apply the questionnaire and, noticing that this 
consumer tends to act in a dysfunctional way, it can ask for more evidences to prove the problem complained by the consumer. Avoiding, with this procedure, sending some apologize gift to someone that doesn't have a real issue.

That said, the central proposal of this study is the development of a scale that differentiates consumers who tend to act in a socially inappropriate manner from those who do not have this tendency.

\section{THEORETICAL REVIEW}

In this session we will present the topics used in the construction of the measurement model proposed: the definition of the concept of dysfunctional consumer behavior and its key drivers.

\subsection{THE DYSFUNCTIONAL CONSUMER BEHAVIOR AND ITS MOTIVATORS}

Over the past few years, studies have investigated dysfunctional consumer behavior. In this study, this behavior will be understood as "actions by customers who intentionally or unintentionally, overtly or covertly, act in a manner that, in some way, disrupts otherwise functional service encounters" (HARRIS; REYNOLDS, 2003, p. 145).

Over the years, the theory of dysfunctional consumer behavior has shown that there are several variables that can motivate it. Among these variables, the ones that have been highlighted as the key motivators in this type of behavior are: the aspects of consumer personality (FULLERTON; PUNJ, 1993; 2004; WIRTZ; KUM, 2004; REYNOLDS; HARRIS, 2009); and the situation in which the consumer is inserted (NYER, 1997; HUEFNER; HUNT, 2000; MCCOLL-KENNEDY et al., 2009; YANI-DE-SORIANO; SLATER, 2009).

With regard to the aspects of personality, the most commonly mentioned are: aggressiveness; self-exposure of the subject; their moral flexibility; and how Machiavellian they are. The situational aspects are: dissatisfaction and influence of others. Below we present these motivators and their respective influence in the socially inappropriate behavior of consumers.

\subsubsection{Aggressiveness}

The aggressive behavior of individuals can be defined as the behavior that intends to cause damage to others, and these seeks to avoid such damage (BERKOWITZ et al., 1986; ANDERSON; BUCHMAN, 2002; RAMÍREZ; ANDREU, 2006; RUVIO; SHOHAM, 2011; POND JR et al., 2012). 
Consumers who act inappropriately can be subdivided into two groups: resistant and aggressive, both verbally and physically (HARRIS; REYNOLDS, 2003). Aggressiveness can be initialized by a dissatisfaction situation (HUEFNER; HUNT, 2000; HARRIS; REYNOLDS, 2003), because such situation can create negative emotions, like anger and frustration, for example (TUZOVIC, 2010).

The issue of rationalization of aggressive can be understood as being one of the most important issues of this behavior and how the individual deals with it (BERKOWITZ et al., 1986; DEWALL et al., 2007; WILKOWSKI; ROBINSON; TROOP-GORDON, 2010). Based on that, individuals with aggressive personality traits may behave more inappropriately than individuals who do not possess these. Therefore, we propose that:

H1: The more aggressive the individual, the greater the tendency to act in a dysfunctional manner.

\subsubsection{Self-Exposure}

At first, when the observers are faced with an individual that they do not know, they compare the behavior and appearance of this individual with the experiences they already had with other individuals who seem to be similar and apply stereotypes based on that memory (GOFFMAN, 1985). That said, the individual, consciously or not, seeks to control the images that are projected in the minds of the observers (SCHLENKER, 1980; O'SULLIVAN, 2000).

The way the individual deals with self-exposure has a key role in human relations, considering the importance given by individuals to how they are seen by others (SCHLENKER, 1980). The disclosure of personal information, secrets, involves risks such as the possibility of rejection, so consumers try to control their self-exposure according to the costs and benefits associated with it (WOLFE; LENNOX; CUTLER, 1986; LEE; IM; TAYLOR, 2008). Given this need, we propose that:

H2: The more the individuals understand that they are able to control their selfexposure to others in social situations, the greater the tendency to act in a dysfunctional manner.

\subsubsection{Moral Flexibility}

Moral Flexibilityis understood as the administration, by the individual, of their ethical and unethical decisions - in which they decide how to act when faced with an ethical dilemma (REYNOLDS, 2006). 
Two models that seek to explain how individuals process their reasoning for making these decisions are: judgment and moral identity. While the first focuses on the moral reasoning of the individual, the second focuses on the self-regulatory mechanisms (AQUINO; REED II, 2002). Both aim to understand how the individual deals with these issues in their decision making (REYNOLDS; CERANIC, 2007).

Moral flexibility is a predecessor of dysfunctional consumer behavior (FULLERTON; PUNJ, 1993; FULLERTON; PUNJ, 2004; WIRTZ; KUM, 2004; REYNOLDS; HARRIS, 2005; SAKALAKI; KANELLAKI; RICHARDSON, 2009). The way individuals deal with moral and ethics are issues inherent to their personality (FULLERTON; PUNJ, 2004; WIRTZ; KUM, 2004; SKARLICKI; VAN JAARSVELD; WALKER, 2008). Thus, the more flexible is the moral of an individual, the more inappropriate their behavior tends to be (WIRTZ; KUM, 2004).Given the direct impact that moral flexibility may cause in the dysfunctional conduct of consumers, we propose that:

H3: The greater the moral flexibility of the individual, the greater the tendency to act in a dysfunctional manner.

\subsubsection{Machiavellianism}

The concept of machiavellianism emerged with the political philosopher Nicolau Maquiavel (1469 - 1527) with the book "The Prince" (1513). In the scope of social sciences, this concept can be understood as a strategy that involves the manipulation of others towards the achievement of individual objectives (GEIS; MOON, 1981; MCHOSKEY, 1995; JAKOBWITZ; EGAN, 2006; SAKALAKI; KANELLAKI; RICHARDSON, 2009; LEARY; ALLEN, 2011).

Machiavellianism is explored in the literature under two aspects: trait or predisposition of an individual's personality, or as strategy of social conduct (LUSTOSA; ROAZZI; CAMINO, 2004). In the first aspect, it is understood that the individual sees nothing wrong in stealing, cheating or lying to achieve their goals (WINTER; STYLIANOU; GIACALONE, 2004). The other aspect, understands that machiavellian can sacrifice the ethics looking to an individual goal, in other words, they act in an unethical way to achieve their personal objectives (GABLE; DANGELLO, 1994 apud LUSTOSA; ROAZZI; CAMINO, 2004, p. $50)$.

With these two aspects in mind, it is understood that machiavellianism directly influences the dysfunctional consumer behavior (REYNOLDS; HARRIS, 2009). Considering 
that both behaviors use strategies that seek to deceive others, and that such deception occurs primarily through the manipulation of information (SKARLICKI; VAN JAARSVELD; WALKER, 2008) we propose that:

H4: The stronger the machiavellian characteristic in the individual, the greater the tendency to act in a dysfunctional manner.

\subsubsection{Dissatisfaction}

Dissatisfaction can be understood as the negative difference between the expectations and the perceived performance of a product by the consumer, being therefore opposed to the concept of satisfaction (ANDERSON, 1973; CHURCHILL JR; SURPRENANT, 1982; KOWALSKI, 1996; OLIVER, 1980; HALSTEAD, 2002; REYNOLDS; HARRIS, 2005; MAGALDI; CRESCITELLI, 2008).

Dissatisfied consumers have shifted their complaints from the private to the public sphere, disclosing them, for example, on the Internet and, with this, being able to spread their dissatisfaction, even though in an inflated or false way (HARRISON-WALKER, 2001; WARD; OSTROM, 2006; WIRTZ; MCCOLL-KENNEDY, 2009; CRONIN; FOX, 2010). In addition, depending on the feelings involved in the situation of dissatisfaction, there is even the possibility that the consumer will end up acting in a socially inappropriate manner.

Thus, in view of the possible impact of dissatisfaction on the dysfunctional consumer behavior, we propose that:

H5: The higher the level of dissatisfaction of the individual at the time of consumption, the greater the impact of situational aspects that stimulate the dysfunctional consumer behavior.

\subsubsection{Acceptance}

The social identity of individuals is their understanding that they belong to a group where they share values and emotions with other members - within which there is, among its members, the sharing of values and emotions (PARK; LESSIG, 1977; WARD; OSTROM, 2006; JOHNSON; MORGESON; HEKMAN, 2012). The feeling of belonging to a group decreases the uncertainty of consumers and makes them feel better as an individual (JOHNSON; MORGESON; HEKMAN, 2012).

In the quest for the perception of belonging to a group, individuals attribute part of their identities to the social groups in which they are inserted (HOGG; TERRY, 2000), the stronger the similarity between group members, the greater the influence of the group in the behavior 
of its members (ROBINSON; O'LEARY-KELLY, 1998). The process of social identity causes individuals to internalize the rules of the groups and align with them, leading to the maximization of similarities within the group and the differences with others (ROBINSON; O'LEARY-KELLY, 1998; HOGG; TERRY, 2000). For this study, it is understood that the individual is inserted in a micro-society that does not accept the dysfunctional consumer behavior and that, for this reason, will avoid acting in such way to keep being accepted by the group. Thus, we developed the following hypothesis:

\section{H6: The more people with the individual, the lower the tendency of the individual}

\section{to accept dysfunctional behavior reactions.}

Table 1 resumes the definition and the literature about each variable used in the construction of the scale developed in this article.

Table 1 - Variables and Each Definition and Literature

\begin{tabular}{|c|c|c|c|}
\hline Variable & Definition & Authors & Hypotesis \\
\hline Aggressiveness & $\begin{array}{l}\text { Behavior that intends to } \\
\text { cause damage to others, } \\
\text { and the subject affected } \\
\text { seeks to avoid such damage }\end{array}$ & $\begin{array}{l}\text { Fornell e Westbrook (1979); } \\
\text { Fullerton e Punj (1993); } \\
\text { Harris e Reynolds (2003); } \\
\text { Huefner e Hunt (2000); } \\
\text { Johnson et al. (2011); } \\
\text { McColl-Kennedy et al. } \\
\text { (2009); Tuzovic (2010); } \\
\text { Ward e Ostrom (2006); } \\
\text { Wetzer et al. (2007) }\end{array}$ & $\begin{array}{l}\text { H1: The more aggressive the } \\
\text { individual, the greater the } \\
\text { tendency to act in a } \\
\text { dysfunctional manner. }\end{array}$ \\
\hline Self-Exposure & $\begin{array}{l}\text { Attempt by the individual, } \\
\text { consciously or not, to } \\
\text { control the image about } \\
\text { them designed by their } \\
\text { observers }\end{array}$ & $\begin{array}{l}\text { Harris e Reynolds (2004); } \\
\text { Johnson, Matear e Thomson } \\
\text { (2011); Nyer (1997); } \\
\text { Wetzer, Zeelenberg e Pieters } \\
\text { (2007); Wirtz e Kum (2004); } \\
\text { Yani-de-Soriano (2009) }\end{array}$ & $\begin{array}{l}\text { H2: The more the } \\
\text { individuals understand that } \\
\text { they are able to control their } \\
\text { self-exposure to others in } \\
\text { social situations, the greater } \\
\text { the tendency to act in a } \\
\text { dysfunctional manner. }\end{array}$ \\
\hline Moral Flexibility & $\begin{array}{l}\text { The administration, by the } \\
\text { individual, of their ethical } \\
\text { and unethical decisions }\end{array}$ & $\begin{array}{l}\text { Fullerton and Punj ( } 1993, \\
\text { 2004); Reynolds e Harris } \\
\text { (2005); Wirtz e Kum (2004) }\end{array}$ & $\begin{array}{l}\text { H3: The greater the moral } \\
\text { flexibility of the individual, } \\
\text { the greater the tendency to } \\
\text { act in a dysfunctional } \\
\text { manner. }\end{array}$ \\
\hline Machiavellianism & $\begin{array}{l}\text { A strategy that involves the } \\
\text { manipulation of others } \\
\text { towards the achievement of } \\
\text { individual objectives }\end{array}$ & $\begin{array}{l}\text { Hegarty e Sims (1979); } \\
\text { Reynolds e Harris (2009); } \\
\text { Wirtz e Kum (2004) }\end{array}$ & $\begin{array}{l}\text { H4: The stronger the } \\
\text { machiavellian characteristic } \\
\text { in the individual, the greater } \\
\text { the tendency to act in a } \\
\text { dysfunctional manner. }\end{array}$ \\
\hline Dissatisfaction & $\begin{array}{l}\text { The negative difference } \\
\text { between the expectations } \\
\text { and the perceived } \\
\text { performance of a product } \\
\text { by the consumer }\end{array}$ & $\begin{array}{l}\text { Harris e Reynolds (2003); } \\
\text { Huefner e Hunt (2000); } \\
\text { Kucuk (2007); Ping Jr e Ping } \\
\text { (1993); Reynolds e Harris } \\
\text { (2009); Ward e Ostrom } \\
\text { (2006); McColl-Kennedy et } \\
\text { al. (2009); Yani-de-Soriano } \\
\text { e Slater (2009) }\end{array}$ & $\begin{array}{l}\text { H5: The higher the level of } \\
\text { dissatisfaction of the } \\
\text { individual at the time of } \\
\text { consumption, the greater the } \\
\text { impact of situational aspects } \\
\text { that stimulate the } \\
\text { dysfunctional consumer } \\
\text { behavior. }\end{array}$ \\
\hline
\end{tabular}




\begin{tabular}{|c|c|c|c|}
\hline Acceptance & $\begin{array}{l}\text { The social identity of } \\
\text { individuals is their } \\
\text { understanding that they } \\
\text { belong to a group - within } \\
\text { which there is, among its } \\
\text { members, the sharing of } \\
\text { values and emotions }\end{array}$ & $\begin{array}{l}\text { Fullerton e Punj (2004); } \\
\text { Reynolds e Harris (2005); } \\
\text { Ward e Ostrom (2006); } \\
\text { McColl-Kennedy et al. } \\
(2009)\end{array}$ & $\begin{array}{l}\text { H6: The more people with } \\
\text { the individual, the lower the } \\
\text { tendency of the individual to } \\
\text { accept dysfunctional } \\
\text { behavior reactions. }\end{array}$ \\
\hline
\end{tabular}

Source: Prepared by the authors

\section{THEORETICAL MODEL}

Given the aspects presented above, we present in Figure 1 a theoretical model for the construction of a measurement instrument in which the variables of the individual's personality and situational aspects appear as influencers of the socially undesirable behavior.

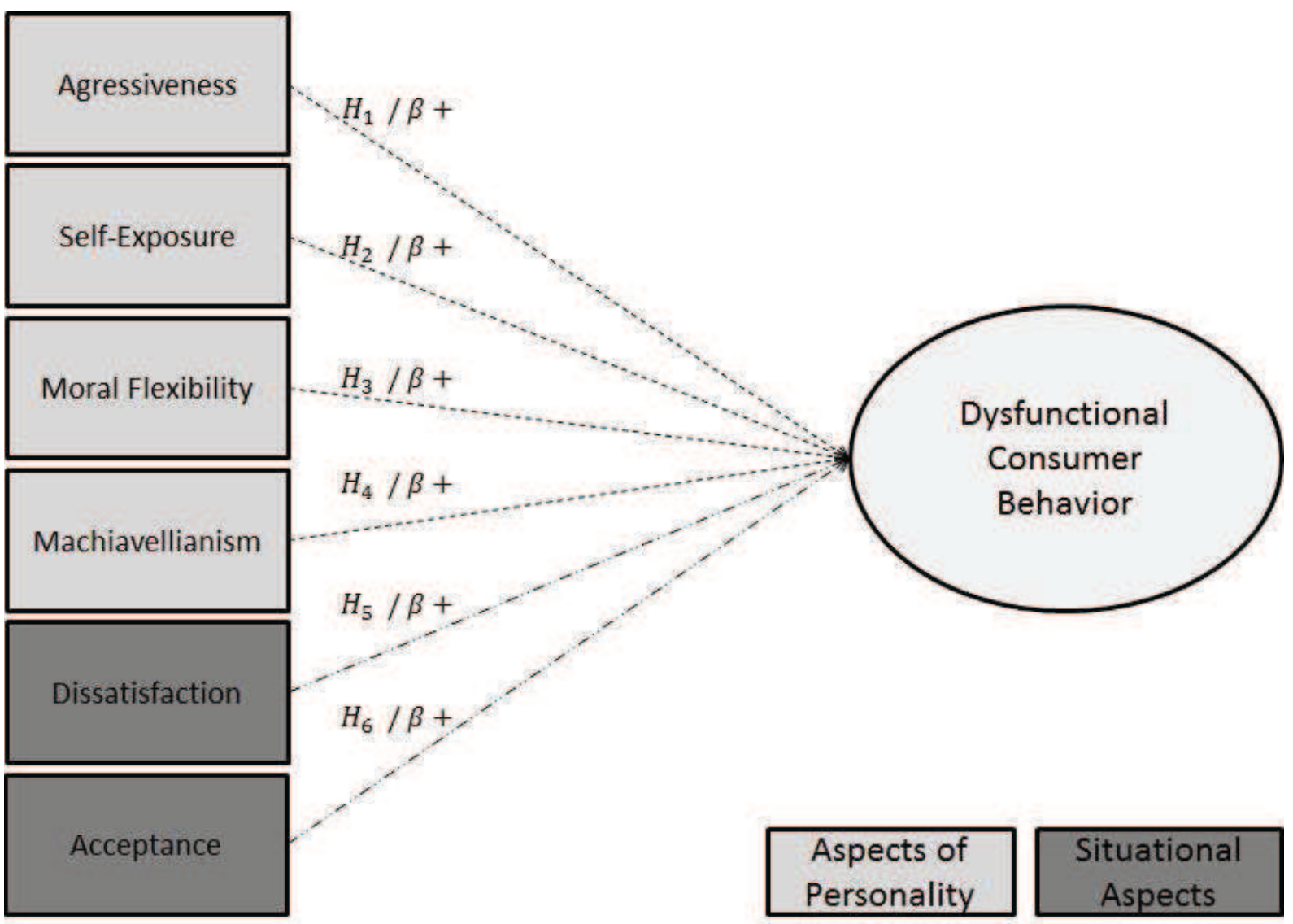

Figure 1: Theoretical Model

Source: Prepared by the authors

The variables regarding the individual's personality considered for the development of the model are: aggression, self-exposure, moral flexibility and machiavellianism. The situational variables are: dissatisfaction and acceptance. It is expected that they all have a positive impact on the dysfunctional consumer behavior, that is, the stronger they are, the higher the probability of the individual to act inappropriately. 


\section{METHODOLOGY}

To build the scale of differentiation of consumers who tend to act in a dysfunctional manner, we have gone through four steps: development of scales; development of the questionnaire for data collection; and the use of the techniques of clusters and discriminant analysis - the first one enables split the respondents that seems to have a higher tendency to act in a dysfunctional manner from the other ones, and the second technique aims to develop the scale based on the results of the clustering technique.

To capture dysfunctional behaviors we developed six stories of a hypothetical consumer and two reactions that he could have to each story. The respondent had to analyze such stories and reactions and classify how pertinent the reactions were. The more he agrees with the reactions, the more he was classify as a dysfunctional consumer.

\subsection{SCALE DEVELOPMENT METHOD}

The measurement, or scale, is at the heart of scientific initiatives (BEARDEN, NETEMEYER; HAWS, 2010).For this study, we opted for a hybrid model of the traditional method of Churchill Jr (1979; CHURCHILL JR, 1979) and the method suggested by Rossiter (2002). The first has a statistical bias in the construction and validation of the scale, while in the second, the research context is the greatest influence on the development of the scale. Both methods have strengths and weaknesses, so we used a joint format for the development of the scale, seeking thereby to take advantage of both (DIAMANTOPOULOS, 2005; FINN; KAYANDE, 2005).

\subsection{FORMATION OF THE CONSTRUCTS OF THE SCALE}

For the development of the constructs used in the scale, we used two methods: the use of previously validated scales; and the development of stories. The first method was used for the collection of some aspects of personality. For each aspect, Table 2 shows the original scale.

Table 2 - Articles of the Scales Used to Measure the Aspects of Personality

\begin{tabular}{ll}
\hline Aspect & Article \\
\hline Aggressiveness & $\begin{array}{l}\text { Richins (1983); Berkowitz, Mueller, et al. } \\
(1986)^{*}\end{array}$ \\
Self-Exposure & Lennox and Wolfe (1984) \\
Moral Flexibility & Aquino and Reed II (2002) \\
Machiavellianism & Chistie and Geis (1970) \\
*Main authors used in the scale & \\
\hline Source: Prepared by the authors
\end{tabular}

Each of the personality constructs has gone through a pre-validation test in which modifications were made to the scales, eliminating the variables that reported unsatisfactory 
results for the formation of the construct. This pre-validation were done using the same tool used to data collection (Mechanical Turk) in the same environment (internet).

Table 3 shows the sentences used for the final scales of each one of the aspects of personality.

Table 3 - Aspects of Personality and Their Variables

\begin{tabular}{|c|c|c|}
\hline Aspect & Cod. & Sentence \\
\hline \multirow[t]{6}{*}{ Aggressiveness } & AG1 & I've already fought with the intent to cause harm to my opponent \\
\hline & AG2 & I use de Internet to quarrel with people \\
\hline & AG3 & $\begin{array}{l}\text { I've already witnessed someone been beaten and I didn't do } \\
\text { anything to stop it }\end{array}$ \\
\hline & AG4 & $\begin{array}{l}\text { I've argued energetically with an attendant that didn't do what I } \\
\text { asked for }\end{array}$ \\
\hline & AG5 & My friends and I used to bully people in school \\
\hline & AG6 & I've already badmouthed a colleague behind his back \\
\hline \multirow[t]{7}{*}{ Self-Exposure } & EX1 & $\begin{array}{l}\text { When I'm introduced to people, I try to fit my behavior in the } \\
\text { way that they expect me to behave }\end{array}$ \\
\hline & EX2 & $\begin{array}{l}\text { I have the ability to change my behavior depending on the social } \\
\text { context that I find myself }\end{array}$ \\
\hline & EX3 & I always try to fit my behavior in the expectations of others \\
\hline & EX4 & $\begin{array}{l}\text { When I 'm with people, I try to adequate my behavior to the } \\
\text { behavior that they have }\end{array}$ \\
\hline & EX5 & $\begin{array}{l}\text { In social situations, I have the ability to alter my behavior if I } \\
\text { feel that something else is called for }\end{array}$ \\
\hline & EX6 & $\begin{array}{l}\text { I have the ability to control the way I come across to people, } \\
\text { depending on the impression I wish to give them }\end{array}$ \\
\hline & EX7 & $\begin{array}{l}\text { I have found that I can adjust my behavior to meet the } \\
\text { requirements of any situation I find myself in }\end{array}$ \\
\hline \multirow[t]{6}{*}{ Moral Flexibility } & FX1 & It's ok to steal to take care of your family's needs \\
\hline & FX2 & $\begin{array}{l}\text { Compared to other illegal things people do, taking some things } \\
\text { from a store without paying for them is not very serious }\end{array}$ \\
\hline & FX3 & $\begin{array}{l}\text { If someone is social pressured into doing something, they } \\
\text { shouldn't be blamed for it }\end{array}$ \\
\hline & FX4 & Teasing someone does not really hurt them \\
\hline & FX5 & People who are mistreated have usually done things to deserve it \\
\hline & FX6 & It is ok to treat badly someone who behaved like a "worm" \\
\hline \multirow[t]{7}{*}{ Machiavellianism } & MQ1 & $\begin{array}{l}\text { Never tell anyone the real reason you did something unless it is } \\
\text { useful to do so }\end{array}$ \\
\hline & MQ2 & $\begin{array}{l}\text { The best way to handle people is to tell them what they want to } \\
\text { hear }\end{array}$ \\
\hline & MQ3 & $\begin{array}{l}\text { There is no problem been dishonest if this help you to be more } \\
\text { successful }\end{array}$ \\
\hline & MQ4 & You are asking for trouble if you completely trust in anyone \\
\hline & MQ5 & $\begin{array}{l}\text { The biggest difference between most criminals and other people } \\
\text { is that criminals are stupid enough to get caught }\end{array}$ \\
\hline & MQ6 & It is wise to flatter important people \\
\hline & MQ7 & $\begin{array}{l}\text { Most people overcome more easily the death of their father than } \\
\text { the loss of their property }\end{array}$ \\
\hline
\end{tabular}

Source: Prepared by the authors 
In order to identify which individuals could behave in a dysfunctional manner or not, six stories were developed of situations faced in the day-to-day by consumers and two dysfunctional reaction for each situation, totaling twelve dysfunctional behavior. The stories developed involved both the issue of dissatisfaction and the influence of others. After reading the stories, the respondent was asked to analyze the reactions that the character had for the situation presented. It is understood, therefore, that the individuals who believe that the reactions were appropriate would be those most prone to act opportunistically.

The collection of these stories was done by following the script: documentary analysis of the key products and services consumed by individuals in their day-to-day; creation of stories and dysfunctional reactions; test of the stories and their reactions; choice of stories with best performance. Table 4 shows the list of stories and reactions with the best results.

Table 4 - Situational Variables

\begin{tabular}{|c|c|c|c|}
\hline $\begin{array}{l}\text { Presence of } \\
\text { Others }\end{array}$ & $\begin{array}{l}\text { Cod } \\
\text { Story }\end{array}$ & $\begin{array}{c}\text { Cod } \\
\text { Reaction }\end{array}$ & $\begin{array}{l}\text { Story in which a situation of dissatisfaction/socially } \\
\text { inappropriate reaction occurs }\end{array}$ \\
\hline \multirow[t]{5}{*}{ Alone } & HSA & HSA_1 & $\begin{array}{l}\text { A person you know left his car with the valet service of a } \\
\text { restaurant, when they returned his car he noticed that the valet } \\
\text { driver had crashed it and the manager of the valet service waived } \\
\text { been liable for damages caused by their employee } \\
\text { Came back in another day and, without anyone noticing, used the } \\
\text { service and didn't pay for it }\end{array}$ \\
\hline & & HSA_2 & $\begin{array}{l}\text { In a distraction moment of the driver, he took the sufficient } \\
\text { amount of money to repair his car from the cash register of the } \\
\text { valet service }\end{array}$ \\
\hline & HSB & & $\begin{array}{l}\text { A person you know bought a book and, when he arrived at home, } \\
\text { he noticed that it was missing a hole chapter in it }\end{array}$ \\
\hline & & HSB_1 & $\begin{array}{l}\text { Scanned and published the book on the internet, without giving } \\
\text { the credits to the real author }\end{array}$ \\
\hline & & HSB_2 & $\begin{array}{l}\text { Got back to the bookstore with gouache red ink hidden in his } \\
\text { pocket and covered the inside pages of some books with it }\end{array}$ \\
\hline \multirow[t]{5}{*}{ With 1 person } & H1A & H1A_1 & $\begin{array}{l}\text { A person you know took his girlfriend to a fancy restaurant in } \\
\text { order to propose. However, the restaurant's waiter treated him } \\
\text { with disdain } \\
\text { In a moment that restaurant's waiter wasn't looking, he put some } \\
\text { broken glass in the plate to simulate that the food was } \\
\text { contaminated - so he wouldn't pay the bill }\end{array}$ \\
\hline & & H1A_2 & $\begin{array}{l}\text { Later on that day he wrote a false e-mail to the restaurant's } \\
\text { manager complaining that he had a food poisoning }\end{array}$ \\
\hline & H1B & & $\begin{array}{l}\text { A person you know had an important meeting with his boss } \\
\text { interrupted by a phone call from his cellphone operator offering a } \\
\text { new plan for his cellphone }\end{array}$ \\
\hline & & H1B_1 & $\begin{array}{l}\text { He disrespected the company's attendant, cursing and threatening } \\
\text { him }\end{array}$ \\
\hline & & H1B_2 & $\begin{array}{l}\text { Later on he made a movie mocking the cellphone operator and } \\
\text { posted it on the Internet }\end{array}$ \\
\hline
\end{tabular}




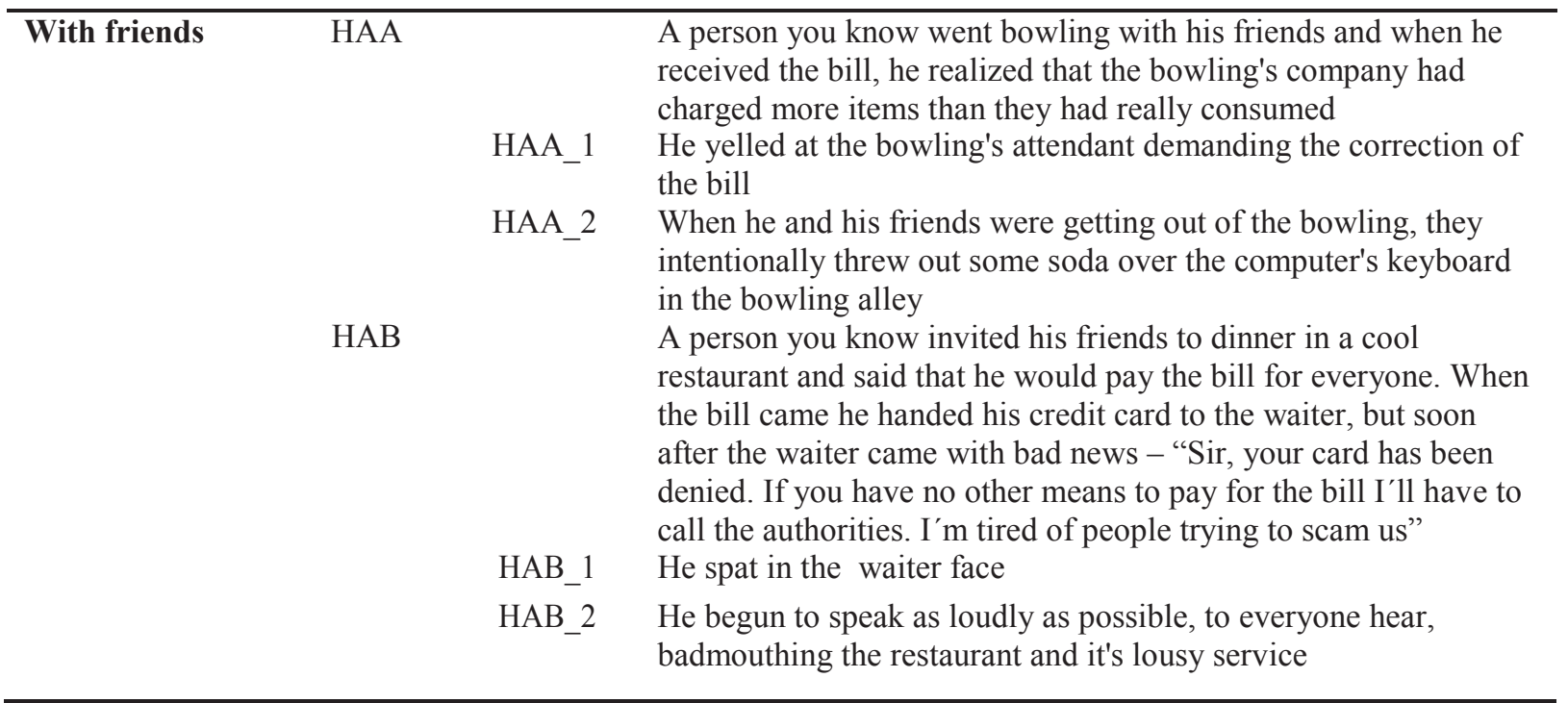

Source: Prepared by the authors

\subsection{CLUSTER AND DISCRIMINANT ANALYSIS}

The cluster analysis was developed with the purpose of separating the respondents into two groups: consumers with high and low tendency to act inappropriately. The techniques used for this separation were the hierarchical cluster analysis, and in a second stage, the nonhierarchical analysis.

The discriminant analysis was used to allow the development of the discriminant function, which will be responsible for discerning consumers who have a tendency to act in a dysfunctional manner from those who do not have this tendency.

\subsection{DATA COLLECTION AND SAMPLING PLAN}

The issue of dysfunctional consumer behavior has a high probability of impact of social desirability bias. Thus, we chose to work with a questionnaire published on a web environment. The tool used for this collection was Mechanical Turk ${ }^{\circledR}$ (AMAZON), or MTurk. This tool has proved to have a reliability equivalent to traditional studies available on the Internet (MASON; SURI, 2012; RAND, 2012). The sample obtained is non-probabilistic (HAIR JR et al., 2009) and the number of respondents achieved, excluding the outliers - that were identified by previously using boxplot analysis, was 432 .

\section{PRELIMINARY DATA ANALYSIS}

The presentation of the data is divided into two phases: in the first phase, called preliminary stage of analysis, we present the characteristics of the sample and the consistency of the constructs measured by the questionnaire; in the second phase we present the analysis of the data using the cluster analysis and discriminant analysis techniques. 


\subsection{CHARACTERISTICS OF THE SAMPLE}

One of the main characteristics of the MTurk tool is that the data sample can be collected in several countries. This research included respondents from the most different countries, but the majority were Americans and Indians (66\% and 27\%, respectively). With regard to the gender, the sample includes $42 \%$ women and $58 \%$ men. The average age of respondents is 33.5 years old.

\subsection{ANALYSIS OF CONSTRUCTS}

For the data to be used in further analyses, it was necessary to investigate the unidimensionality of the constructs measured by the questionnaire (GERBING; ANDERSON, 1988). The Table 5 shows the results obtained through Chronbach's Alpha and indices of factor analysis for the constructs.

Table 5 - Results of the Analyzes of the Constructs

\begin{tabular}{|c|c|c|c|c|c|c|c|}
\hline \multirow{2}{*}{ Construct } & \multirow{2}{*}{ Group } & \multirow{2}{*}{ Variables } & \multirow{2}{*}{$\begin{array}{c}\text { Cronbach's } \\
\text { Alpna }\end{array}$} & \multirow{2}{*}{ zмmo } & \multirow{2}{*}{$\begin{array}{c}\text { Bartlett's } \\
\text { (sig.) }\end{array}$} & \multicolumn{2}{|c|}{ Components } \\
\hline & & & & & & & G2 \\
\hline Aggressiveness & & (all) & 0.800 & 0.833 & 0.000 & $1 \mathrm{ce}$ & \\
\hline \multirow[t]{7}{*}{ Exposure } & \multirow{4}{*}{$\begin{array}{l}\text { Social } \\
\text { Situation }\end{array}$} & EX2 & 0.851 & 0.847 & 0.000 & 0.838 & \\
\hline & & EX5 & & & & 0.804 & \\
\hline & & EX7 & & & & 0.708 & \\
\hline & & EX6 & & & & 0.701 & \\
\hline & \multirow{3}{*}{$\begin{array}{l}\text { Expectation of } \\
\text { People }\end{array}$} & EX3 & 0.851 & & & & 0,854 \\
\hline & & EX1 & & & & & 0,827 \\
\hline & & EX4 & & & & & 0,806 \\
\hline \multicolumn{2}{|l|}{$\begin{array}{l}\text { Moral } \\
\text { Flexibility }\end{array}$} & (all) & 0.836 & 0.830 & 0.000 & $1 \mathrm{ce}$ & \\
\hline \multicolumn{2}{|l|}{ Machiavellianism } & (all) & 0.780 & 0.838 & 0.000 & $1 \mathrm{ce}$ & \\
\hline \multicolumn{2}{|l|}{$\begin{array}{l}\text { Dissatisfaction and } \\
\text { Influence }\end{array}$} & (all) & 0.893 & 0.904 & 0.000 & N/A & \\
\hline \multicolumn{2}{|l|}{$\begin{array}{l}\text { Dysfunctional } \\
\text { Consumer Behavior }\end{array}$} & (all) & 0.899 & 0.920 & 0.000 & N/A & \\
\hline ce $=$ components ext & cted & & & & & & \\
\hline
\end{tabular}

For all constructs analyzed we obtained positive results for the Cronbach's alpha, (HAIR JR. et al., 2009) higher than 0.700 .

For personality constructs, we obtained appropriate rates of factor analysis, KMO (with the results above 0,7 for the first indicator, and the second one above 0,8) and Bartlett's, significant to all variables (HAIR JR et al., 2005).For the other two constructs we chose to use 
all the variables, as we believe that this would be more interesting for further analyses (cluster and discriminant).

\subsection{CLUSTER ANALYSIS}

The separation of the respondents was performed through cluster analysis, in which it is possible to group individuals into homogeneous groups according to the degree of similarity of their responses for the variables of dysfunctional consumer behavior (FÁVERO et al., 2009).These variables were created through the combination of the responses of individuals with the variables of reaction to the stories, thus creating a new variable: CI_2, a taxonomic variable used in the separation of the groups.

For the clustering of individuals, it was conducted a hierarchical analysis, and then, a non-hierarchical. (HAIR JR. et al., 2009) In the first one, it is possible to see how many groups could be formed with the database, as well as the identification of atypical observations and centroids that were used in the non-hierarchical analysis.

We chose to use the average linkage as clustering algorithm, since it generates groups with little internal variation, has lower impact of extreme values, and because it is expected that groups may have different sizes (HAIR JR. et al., 2009).Given the results, using the stopping rule, we work with two groups. By comparing them, through the statistical comparison of their averages, it was found that they were statistical different.

To perform the non-hierarchical analysis, we used the data obtained from the hierarchical analysis (HAIR JR. et al., 2005; HAIR JR. et al., 2009). The two resulting groups also indicated that they were statistical different.

Analyzing the average response for the variable Inappropriate Behavior (Table 6) it can be seen that G1 has a higher mean than G2 - which may indicate a greater tendency for this group to act inappropriately.

Table 6- Descriptive Data of Variable CI_2 for the Groups Formed by the Non-Hierarchical Method

\begin{tabular}{lllll} 
& & & \multicolumn{2}{l}{ Confidence Interval: 95\% } \\
\cline { 4 - 5 } & & Mean & Lower Bound & $\begin{array}{r}\text { Upper } \\
\text { Bound }\end{array}$ \\
$\mathbf{1}$ & 139 & 32.086 & 31.125 & 33.048 \\
$\mathbf{2}$ & 293 & 15.267 & 14.785 & 15.749 \\
Total & 432 & 20.679 & 19.811 & 21.547 \\
\hline Source: Research data & & &
\end{tabular}

Given the division of groups by the non-hierarchical method, it is necessary to check whether the groups present statistically different responses for the constructs of personality 
and for the situational constructs. In Table 7 we present the results of the statistically significance.

Table 7 - ANOVA of Personality Constructs and Stories

\begin{tabular}{cc}
\hline Variable & Sig. \\
\hline AG & $.000^{*}$ \\
EXP & $.003^{*}$ \\
FX & $.098^{* * *}$ \\
MQ & $.000^{*}$ \\
HS & $.000^{*}$ \\
H1 & $.000^{*}$ \\
HA & $.000^{*}$ \\
\hline $\begin{array}{l}\text { Legend: * sig. for alpha } \mathbf{0 , 0 1} / * * \text { sig. for } \\
\text { alpha 0,10 }\end{array}$ \\
\hline Source: Research data \\
\hline
\end{tabular}

It can be seen that there is a significant difference between all constructs for both groups. By comparing the results of the two methods (hierarchical and non-hierarchical), it is found that $87 \%$ of the respondents were classified in the same way by both methods, which indicates that the cluster is appropriate (HAIR JR. et al., 2005).

\subsection{DISCRIMINATE ANALYSIS}

After the clustering of individuals, we conducted the discriminant data analysis. The purpose of this analysis is to propose a discriminant equation able to separate individuals according to their tendency to act in a socially inappropriate manner, through personality and situational aspects. For this analysis, the sample was divided into two groups, the first will be used for building the discriminant equation and the second for its validation.

The dependent variable is categorical, independent variables are formed by the personality and situational constructs. The main assumption for performing the discriminant analysis is that there is multivariate normality (HAIR JR. et al., 2009). To verify this, we performed three tests: Normal QQ plot, the Kolmogorov-Smirnov normality test and the box's M test. All of which indicated multivariate normality among the data.

To estimate the discriminant equations, we used the simultaneous method. By performing the discriminant analysis we started the process of evaluation of the conditions of predictive accuracy of data. The Wilk's Lambda (0.497) statistics appeared to be significant (HAIR JR. et al., 2005), indicating statistical difference between the groups. After that, is important to analyze the significance of the discriminant variables individually (Table 8). 
Table 8 - Statistical Significance of Discriminant Variables

\begin{tabular}{cc}
\hline Variables & Sig. \\
\hline AG & .000 \\
MQ & .000 \\
HS & .000 \\
H1 & .000 \\
HA & .000 \\
EXP & .001 \\
FX & .004 \\
\hline Source: Research
\end{tabular}

By analyzing Table 8, it can be seen that all variables indicate good predictive power between the groups. Considering, therefore, all seven variables, we obtain the discriminant equation below:

\section{Equation 1 - Discriminant equation}

$$
\begin{gathered}
Z=-4,671+(A G \times 0,625)+(H S \times 0,797)+(M Q \times 0,365)+(H A \times 0,039)+(H 1 \times(-0,228)) \\
+(E X P \times 0,036)+(F X \times 0,251)
\end{gathered}
$$

Source: Research data

After classifying the groups in a statistically significant manner, we then analyze the predictive power of the discriminant function, developing the classification matrix - which will evaluate the accuracy of the classifications. According to the calculation of the general pattern of comparison, the criterion of proportional chances is $56.5 \%$, to be considered a good overall accuracy of the model it should be at least $70.6 \%$, in this research it is $87.8 \%$, and can be, therefore, classified as good. Table 9 shows the percentage of general and specific classification.

Table 9 - Results of the Classification of the Groups Through the Discriminant Function

\begin{tabular}{cccccc}
\hline Case number in the cluster & \multicolumn{3}{c}{ Estimated participation in group } & Total \\
\hline & & $\mathbf{1}$ & 69.0 & 31.0 & 100.0 \\
Group & $\%$ & & & & \\
& & G1 & 3.3 & 96.7 & 100.0 \\
\hline
\end{tabular}

a. $87.8 \%$ of individuals were classified in the same group as originally

Source: Research data

It can be seen also that the estimate for the groups are equally good. For both groups, the results of the discriminant function were better than the minimum percentage (for the G1 result of $69 \%$ compared to the minimum of $40 \%$; and for G2 $96.7 \%$, compared to $85 \%$ ). 


\section{DATA ANALYSIS}

The main purpose of this study was to identify the consumer who tends to behave in a dysfunctional manner through personality and situational aspects. For that, we identified in the literature aspects that could be associated with this behavior. These aspects would be used to compose the discriminant function that would separate individuals who are more likely to act in dysfunctional manner versus those with a lower tendency.

\subsection{CLUSTER ANALYSIS}

Through the cluster analysis, it is possible to see that the individuals can be divided into two statistically different groups (Table 10).

Table 10 - Variables Versus Means of the Groups in the Clusters

\begin{tabular}{lccc}
\hline \multirow{2}{*}{ Construct } & Variables & \multicolumn{2}{c}{ Means } \\
\cline { 2 - 4 } & & G1 & G2 \\
\hline Aggressiveness & AG & 3.5442 & 1.9628 \\
Self-Exposure & EXP & 4.0694 & 3.4742 \\
Moral Flexibility & FX & 4.1151 & 3.5699 \\
Machiavellianism & MQ & 3.9449 & 2.7888 \\
Dissatisfaction & HS & 2.9057 & 1.3896 \\
& H1 & 2.6981 & 1.7362 \\
& HA & 2.7406 & 1.7163 \\
\hline Acceptance & CI_alone & 3.1910 & 1.7316 \\
& CI_1person & 3.1486 & 1.7906 \\
\hline Dysfunctional Behavior & CI_afriends & 2.9741 & 1.6702 \\
\hline & CI_2 & $\mathbf{3 . 1 0 4 7}$ & $\mathbf{1 . 7 3 0 7}$ \\
\hline
\end{tabular}

Source: Research data

It is possible to classify $\mathrm{G} 1$ as the one that has the greatest tendency to act in a dysfunctional manner - given the result obtained for CI_2 versus for G2. In view of this differentiation, it is possible to analyze the profile of each of them in relation to the personality and situational constructs.

According to the means of the responses, G1 has individuals with a greater tendency to aggressiveness. Furthermore, according to the data obtained, they appear to be more concerned about their self-exposure to others, greater moral flexibility and machiavellianism. 
With respect to the situational aspects, we see that this group appeared to be more dissatisfied with the situations presented and more affected by the presence of others.

By this results, therefore, it is possible to say that the data collected supports the theoretical model proposed. It means that both the personality and situational aspects have a direct impact on the inappropriate consumer behavior. And the more intense they are, the greater the impact on this behavior.

\subsection{DISCRIMINATE ANALYSIS}

After deciding that the discriminant function should not be invalidated, we used the validation sample to analyze the equation obtained. The results obtained in the validation were satisfactory (Table 11), since the minimum percentage of general classification should be $78.4 \%$, that is, lower than the $81 \%$ obtained by the equation.

Table 11 - Results from the Classification of the Samples

\begin{tabular}{lccccc} 
& \multicolumn{2}{c}{ Development Sample } & & \multicolumn{2}{c}{ Validation Sample } \\
\cline { 2 - 3 } \cline { 5 - 6 } G1 & Minimum & Observed & & Minimum & Observed \\
G2 & $40.0 \%$ & $69.0 \%$ & & $30.90 \%$ & $77 \%$ \\
\hline Total & $85.0 \%$ & $96.7 \%$ & & $94.0 \%$ & $82.0 \%$ \\
\hline Source: & $\mathbf{7 0 . 6 \%}$ & $\mathbf{8 7 . 8 \%}$ & & $\mathbf{7 8 . 4 \%}$ & $\mathbf{8 1 . 0} \%$ \\
\hline
\end{tabular}

With respect to the predictability of the groups, it was found that the classification of G1 is sufficiently good (77\% achieved versus 30.9\% minimum), yet the G2 did not obtain predictability greater than the minimum ( $82 \%$ achieved versus $94 \%$ minimum).

Although the minimum predictability was not achieved for G2, we chose not to invalidate the discriminant function, since it managed to sufficiently differ G1 - the main target of this study, and also differentiated the entire group in general.

With regard to the difference of the group means, it could be seen that all variables were significant. Thus indicating that the groups statistical different.

\subsection{ANALYSIS OF THE HYPOTHESES}

Considering the results obtained in the clusters and in the discriminant analysis, it is necessary to analyze the hypotheses in view of the results found (Table 12). 
Table 12 - Results of Acceptance of Hypotheses

\begin{tabular}{lcc}
\hline Construct & Hypothesis & Acceptance/Rejection \\
\hline Aggressiveness & $\mathrm{H} 1$ & Accepted \\
Self-Exposure & $\mathrm{H} 2$ & Accepted \\
Moral Flexibility & $\mathrm{H} 3$ & Accepted \\
Machiavellianism & $\mathrm{H} 4$ & Accepted \\
Dissatisfaction & $\mathrm{H} 5$ & Rejected \\
Acceptance & $\mathrm{H} 6$ & Accepted \\
\hline
\end{tabular}

Source: prepared by the author

Hypothesis H5 proved to be inconsistent, since it indicated different results for each of the evaluation methods, and is therefore rejected. The other hypotheses indicated satisfactory results, that is, it is possible to accept them.

\section{FINAL CONSIDERATIONS}

The main purpose of this study was to identify the consumer who tends to have a dysfunctional behavior through personality and situational aspects. In this study, the socially undesirable behavior was understood as the behavior adopted by certain consumers and that is against the rules and regulations established by the society in which they are inserted, during the consumption of a product and/or service.

As found in the literature review, there are evidences that certain personality traits and situations that can influence consumer behavior, making them act in a dysfunctional manner. Next we will discuss the results of this study, as well as its academic and managerial implications, limitations and suggestions for future studies.

\subsection{DISCUSSION OF RESULTS}

Through the study presented in this article, it was possible to note that the personality characteristics seem to positively influence the socially undesirable consumer behavior. Out of the four aspects studied it was found that apparently aggressiveness and machiavellianism are those with the greatest impact on behavior.

The aggressive individual was defined by this study as the one who acts in a way to try to cause damage to others, and that the latter wants to avoid this damage. The machiavellian individual can be understood as the one who seeks to manipulate other people, understanding that such manipulation is simply a means to reach an end.

When these two definitions are compared to that of dysfunctional behavior, it can be seen that the result obtained supports the theory. As Reynolds and Harris (2009) commented on their research, these factors are strongly associated with the dysfunctional consumer behavior. 
The moral flexibility and the self-exposure of the individual didn't show as important variables for the differentiation of the study. On the other hand, by outlining the characteristics of the groups classified through the discriminant function, we found a significant difference in these variables at the individuals belonging to the groups.

The situational issues in this study were placed to individuals in the form of stories. In theory, it was expected that dissatisfaction was directly related to the dysfunctional behavior, as indicated by, for example, McColl-Kennedy, Patterson et al. (2009) and Reynolds and Harris (2009). However, in this study, the individuals in the group with the greatest tendencies to act in dysfunctional manner appeared to be less dissatisfied with the situation than those who did not shown the tendency of such behavior.

The analysis of the level of acceptance of the inappropriate reactions described in the stories for each group showed that the more people are with the individual, more appropriate is his behavior. This conclusion is consistent with the theory, which advocates that individuals adapt their behavior to align to what they believe to be the most socially acceptable (HOGG; TERRY, 2000).

One last important point to be discussed is the quality of the classification achieved through the discriminant analysis. We achieved the main purpose of this study, which was to identify the consumer who tends to behave in a dysfunctional manner through personality and situational aspects. The accuracy of the classification of G2, which was not as satisfying - as discussed previously - do not eliminate the merits of the rest of the equation.The error that this low accuracy implies is in the classification of consumers who would not tend to act in a socially inappropriate manner as consumers who may act in such manner.

Since it is not suggested here that the organization that identifies this trend in a consumer would no longer serve it, but start observing it more carefully, it can be said that the result of the classification has a more conservative nature. This is because the discriminant function will slightly inflate the result of customers who must be accompanied with greater care, which need not be considered as something negative.

\subsection{ACADEMIC AND MANAGERIAL IMPLICATIONS AND SUGGESTIONS FOR FUTURE STUDIES}

This study aimed to contribute to the construction of academic knowledge regarding the socially undesirable consumer behavior. As noted by Fisk, Harris, et al. (2010), the literature lacks a scale that measures the socially undesirable consumer behavior. This study had the intention to contribute to this underexplored aspect, bringing the development of a scale that 
enables the indirect discrimination of consumers who may have a tendency to act inappropriately.

With respect to the marketing and business management strategy, this study aims to bring a new tool for managers to manage their customer base. With the scale developed, it is possible that the organization identifies a consumer as a potential socially inappropriate consumer and can thereby monitor their behavior during the relationship with the organization.

One of the main limitations of the study is that, with regard to the development of the scale, there is a limitation as to the classification of individuals who have a lower tendency to act in socially inappropriate manner. This is because it was found in the study that the classification of these individuals did not reach a satisfactory level. Furthermore, the data collection method was not random - which prevents the generalization of the results.

For future studies, we suggest the investigation of this type of behavior in the virtual environment - comparing behavioral tendencies in this and in the offline environment, seeking to explore if on consumers have dysfunctional behavior more frequently than off-line consumers. Finally, the analysis of consumer groups, after the application of the discriminant scale, indicated that the groups had certain differences with respect to their age, sex and country of origin. We believe that it would be interesting to conduct a survey to assess the impact of these demographic variables in the socially undesirable behavior of consumers.

\section{REFERENCES}

AMAZON. Mechanical turk. Disponivel em: <https://www.mturk.com/mturk/welcome>. Acesso em: 11 fev. 2013.

ANDERSON, C. A.; BUCHMAN, B. J. Human Aggression. Annual Review of Psychology, v. 53, p. 27-51, 2002.

ANDERSON, R. Consumer dissatisfaction: the effect of disconfrimed expectancy on perceived product performance. Journal of Marketing Research, v. 10, n. 1, p. 38-44, 1973.

AQUINO, K.; REED II, A. The Self-importance of moral identity. Journal of Personality and Social Psychology, v. 83, n. 6, p. 1423-1440, 2002.

BEARDEN, W.; NETEMEYER, R.; HAWS, K. Handbook of marketing scales: multi-item measures for marketing and consumer behavior research. [S.1.]: Sage Publication, 2010. 603 p.

BERKOWITZ, M. W. et al. Moral Reasoning and Judments of Aggression. Journal of Personality and Social Psychology, v. 51, n. 4, p. 885-891, 1986. 
CHRISTIE, R.; GEIS, F. Studies in Maquiavellianism. Nova York: Academic Press, 1970.

CHURCHILL JR, G. A paradigm for developing better measures of marketing constructs. Journal of Marketing Research, v. 16, n. 1, p. 64-73, 1979.

CHURCHILL JR, G. A.; SURPRENANT, C. An investigation into customer the determinants of satisfaction. Journal of Marketing Research, v. 19, n. 4, p. 491-504, 1982.

CRONIN, J. J.; FOX, G. L. The implications of third-party customer complaining for advertising efforts. Journal of Advertising, v. 39, n. 2, p. 21-34, 2010.

DEWALL, C. N. et al. Violence restrained: Effects of self-regulation and tis depletion making: a study of antecedents and outcomes. Journal of Experimental Social Psychology, v. 43, n. 1, p. 62-76, 2007.

DIAMANTOPOULOS, A. The C-OAR-SE procedure for scale development in marketing: a comment. Internationl Journal of Research in Marketing, v. 22, n. 1, p. 1-9, 2005.

FÁVERO, L. et al. Análise de dados. Rio de Janeiro: Elsevier, 2009.

FINN, A.; KAYANDE, U. How fine is C-OAR-SE? A generalizability theory perspective on Rossiter's procedure. International Journal of Research in Marketing, v. 22, n. 1, p. 11-21, 2005.

FISK, R. G. S. et al. Customers behaving badly: a state of the art review, research agenda and implications for practitioners. Journal of Services Marketing, v. 24, n. 6, p. 417-429, 2010.

FORNELL, C.; WESTBOOK, R. A. An exploratory study of assertiveness, aggressiveness, and consumer complaining behavior. Advances in Consumer Research, v. 6, n. 1, p. 105$110,1979$.

FULLERTON, R. A.; PUNJ, G. Choosing to misbehave: a structural model or aberrant consumer behavior. Advances in Consumer Research, v. 20, p. 570-574, 1993.

FULLERTON, R. A.; PUNJ, G. Repercussions of promoting an ideology of consumption: consumer misbehavior. Journal of Business Research, v. 57, n. 11, p. 1239-1249, nov. 2004.

GABLE, M.; DANGELLO, F. Locus of control, Machiavellianism, and Managerial Job Performance. The Journal of Psychology, 128, p. 599-608, 1994.

GEIS, F. L.; MOON, T. H. Machiavellianism and deception. Journal of Personality and Social Psychology, v. 41, n. 4, p. 766-775, 1981.

GERBING, D.; ANDERSON, J. An updated paradigm for scale development incorporating unidimensionality and its assessment. Journal of Marketing Research, v. 25, n. 2, p. 186192, 1988.

GOFFMAN, E. A representação do eu na vida cotidiana. 11. ed. Petrópolis: Vozes, 1985.

HAIR JR, J. et al. Fundamentos de Metodos de Pesquisa Em Administração. Porto Alegre: Bookman, 2005. 
et al. Análise Multivariada de Dados. 6. ed. Porto Alegre: Bookman, 2009.

HALSTEAD, D. Negative word of mouth: substitute for supplement to consumer complaints? Journal of Consumer Satisfaction, Dissatisfaction and Complaining Behavior, v. 15, p. 1$12,2002$.

HARRIS, L. C.; REYNOLDS, K. L. The Consequences of Dysfunctional Customer Behavior. Journal of Service Research, 6, n. 2, p. 144-161, 2003.

;. Jaycustomer behavior: an exploration of types and motives in the hospitality industry. The Journal of Services Marketing, v. 18, n. 4, p. 339-357, 2004.

HARRISON-WALKER, L. J. E-complaining: a content analysis of an Internet complaint forum. Journal of Services Marketing, v. 15, n. 5, p. 397-412, 2001.

HEGARTY, W. H.; SIMS, H. P. Organizational philosophy, policies, and objectives related to unethical decision behavior: A laboratory experiment. Journal of Applied Psychology, v. 64, n. 3, p. 331-338, 1979.

HOGG, M.; TERRY, D. Social identity and self-categorization processes in organizational contexts. Academy of Management Review, v. 25, n. 1, p. 121-140, 2000.

HUEFNER, J. C.; HUNT, H. K. Consumer Retaliation as a Response to Dissatisfaction. Journal of Consumer Satisfaction, Dissatisfaction and Complaining Behavior, v. 13, p. 61-82, 2000.

JAKOBWITZ, S.; EGAN, V. The dark triad and normal personality traits. Personality and Individual Differences, v. 40, n. 2, p. 331-339, 2006.

JOHNSON, M.; MORGESON, F.; HEKMAN, D. Cognitive and affective identification: exploring the links between different forms of social identification and personality whith work attitudes and behavior. Journal of Organizational Behavior, v. 33, p. 1142-1167, 2012.

KOWALSKI, R. M. Complaints and complaining: functions, antecedents, and consequences. Psychological Bulletin, v. 119, n. 2, p. 179-1996, 1996.

KUCUK, S. U. Negative Double Jeopardy: The role of anti-brand sites on the internet. Journal of Brand Management, 15, n. n. 3, p. 209-222, 2007.

LEARY, M. R.; ALLEN, A. B. Self-presentational persona: simultaneus management of multiple impressions. Journal of Personality and Social Psychology, v. 101, n. 5, p. 10331049, 2011.

LEE, D. H.; IM, S.; TAYLOR, C. R. Voluntary self-disclosure of information on the Internet: A multimethod study of the motivations and consegquences of disclosing information on blogs. Psychology and Marketing, v. 25, n. 7, p. 692-710, 2008.

LENNOX, R.; WOLFE, R. Revisionof the self-monitoring scale. Journal of Personality and Social Psychology, v. 46, n. 6, p. 1349-1364, 1984. 
LUSTOSA, A. V.; ROAZZI, A.; CAMINO, C. Maquiavelismo: um construto psicológico. Estudos e PEsquisas em Psicologia, v. 4, n. 1, p. 48-62, 2004.

MAGALDI, S.; CRESCITELLI, E. A importÂncia dos serviços suplementares no setor de serviços: uma análise do nível de satisfação do cliente. Revista de Gestão USP, v. 15, n. 3, p. 67-75, 2008 .

MALHOTRA, N. Pesquisa de Marketing: uma orientação aplicada. 4. ed. Porto Alegre: Bookman, 2006. 720 p.

MARCONI, M.; LAKATOS, E. Fundamentos da Metodologia Cientifica. São Paulo: Atlas, 2005.

MASON, W.; SURI, S. Conducting behavioral research on Amazon's Mechanicar Turk. Behavior Research Methods, v. 44, p. 1-23, 2012.

MCCOLL-KENNEDY, J. R. et al. Customer Rage Episodes: Emotions, Expressions and Behaviors. Journal of Retailing, v. 85, n. 2, p. 222-237, 2009.

MCHOSKEY, J. Narcissism and Machiavellianism. Psychological Reports, v. 77, n. 3, p. 755-759, 1995.

NEALE, L.; FULLERTON, S. The international search for ethics norms: which consumer behaviors to consumers consider (un)acceptable? Journal of Services Marketing, v. 24, n. 6, p. 476-486, 2010.

NYER, P. U. A Study of the Relationchips between Cognitive Appraisals and Consumption Emotions. Journal of the Academy of Marketing Science, v. 25, n. 4, p. 296-304, 1997.

OLIVER, R. L. A cognitive model of the antecedents and consequences of satisfaction decisions. Journal of Marketing Research, v. 17, n. 4, p. 460-469, 1980.

O'SUllivan, B. What you don't know won't hurt me. Human Communication Research, v. 26, n. 3, p. 403-431, 2000.

PARK, C.; LESSIG, V. Students and housewives: Differences in susceptibility to reference group influence. Journal of Consumer Research, v. 4, n. 1952, p. 102-110, 1977.

PING JR, R. A.; PING, A. The effects of satisfaction and structural constraints on retailer exiting, voice, loyalty, opportunism, and neglect. Journal of Retailing, 69, n. n. 3, p. 320$352,1993$.

POND JR, R. S. et al. Repulsed by violence: disgust sensitivity buffers trait, behavioral, and daily aggression. Journal of Personality and Social Psychology, v. 102, n. 1, p. 175-188, 2012.

RAMÍREZ, J. M.; ANDREU, J. M. Aggression, and some related psychological constructs (anger, hostility, and impulsivity); some comments from a research project. Neuroscience and biobehavioral reviews, v. 30, n. 3, p. 276-291, 2006.

RAND, D. The Promisse of Mechanical Turk: how online labor markets can help theorists run behavioral experiments. Journal of Theoretical Biology, v. 299, p. 172-179, 2012. 
REYNOLDS, K. L.; HARRIS, L. C. Dysfunctional Customer Behavior Severity: An Empirical Examination. Journal of Retiling, v. 85, n. 3, p. 321-335, 2009.

REYNOLDS, K. L.; HARRIS, L. C. Dysfunctional Customer Behavior Severity: An Empirical Examination. Journal of Retailing, v. 85, n. 3, p. 321-335, 2009.

REYNOLDS, S. J. Moral awareness and Ethical predispositions: investigating the role of individual differences in the recognition of moral issues. The Journal of Applied Psychology, v. 91, n. 1, p. 233-243, 2006.

REYNOLDS, S. J.; CERANIC, T. L. The effects of moral judment and moral identity on moral behavior: an empirical examination of the moral issues. The Journal of Applied Psychology, v. 92, n. 6, p. 1610-1624, 2007.

REYNOLDS, S. J.; HARRIS, L. C. When service failure is not service failure: an exploration of the forms and motives of "ilegitimate" customer complaining. Journal of Services Marketing, v. 19, n. 5, p. 321-335, 2005.

RICHINS, M. An analysis of consumer interaction styles in the marketplace. Journal of Consumer Research, v. 10, p. 73-82, 1983.

ROBINSON, S.; O'LEARY-KELLY, A. Monkey see, monkey do: the influence of work groups in the antisocial behavior of employees. Academy of Management Journal, v. 41, n. 6, p. 658-672, 1998.

ROSSITER, J. The C-OAR-SE procedure for scale development in marketing. Internationl Journal of Research in Marketing, v. 19, n. 4, p. 305-335, 2002.

RUVIO, A. A.; SHOHAM, A. Aggressive driving: A consumption experience. Psychology and Marketing, v. 28, p. 1089-1114, nov. 2011.

SAKALAKI, M.; KANELLAKI, S.; RICHARDSON, C. Is a manipulator's externality paradoxical? The relationship between Machiavellianism, economic opportunism, and economic locus of control. Journal of Applied Social Psychology, v. 39, n. 11, p. 25912603, 2009.

SCHLENKER, B. R. Impression Management: The Self-Concept Social Identity, and Interpersonal Relations. Monterey: Brooks/Cole Publishing Company, 1980.

SKARLICKI, D. P.; VAN JAARSVELD, D. D.; WALKER, D. D. Getting even for customer mistreatment: the role of moral identity in the relationship between customer interpersonal injustice and employee sabotage. The Journal of Applied Psychology, v. 93, n. 6, p. 13361347, 2008.

TUZOVIC, S. Frequent (flier) frustration and the dark side of word-of-web: exploring online dysfunctional behavior in online feedback forums. Journal of Services Marketing, v. 24, n. 6, p. 446-457, 2010.

VLEEMING, R. G. Machiavellianism: A preliminary review. Psychological Reports, v. 44, p. 295-310, 1979. 
WARD, J. C.; OSTROM, A. L. Complaining to the masses: The role of protest framing in customer-created complaint web sites. Journal of Consumer Research, v. 33, n. 2, p. 220 $230,2006$.

WETZER, I. M.; ZEELENBERG, M.; PIETERS, R. "Never Eat In That Restaurant, I Did!": Exploring Why People Engage In Negative Word- Of-Mouth Communication. Psychology and Marketing, 24, n. n. 8, p. 661-680, 2007.

WILKOWSKI, B. M.; ROBINSON, M. D.; TROOP-GORDON, W. How does cognitive control reduce anger and aggression? The role of conflict monitoring and forgiveness processes. Journal of Personality and Social Psychology, v. 98, n. 5, p. 830-840, 2010.

WINTER, S. J.; STYLIANOU, A. C.; GIACALONE, R. A. Individual differences in the acceptability of unethical information technology practices: The case of Machiavellianism and ethical ideology. Journal Business Ethics, v. 54, p. 279-301, 2004.

WIRTZ, J.; KUM, D. Consumer Cheating on Service Guarantees. Journal of the Academy of Marketing Science, v. 32, n. 2, p. 159-175, 2004.

WIRTZ, J.; MCCOLL-KENNEDY, J. R. Opportunistic customer claiming during service recovery. Journal of the Academy of Marketing Science, v. 38, n. 5, p. 654-675, 2009.

WOLFE, R. N.; LENNOX, R. D.; CUTLER, B. L. Getting Along and Getting Ahead: Empirical Support for a Theory of Protective and Acquisitive Self-Presentation. Journal of Personality and Social Psychology, v. 50, n. 2, p. 356-361, 1986.

YANI-DE-SORIANO, M.; SLATER, S. Revisiting Druker's theory: Has consumerism led to the overuse of Marketing? Journal of Marketing History, v. 15, n. 4, p. 452-466, 2009. 